\title{
The Notion of Common and Social Representations
}

\author{
Denise Jodelet \\ School for Advanced Studies in the Social Sciences, \\ 54 Boulevard Raspail, Paris, 75006, French Republic \\ $\checkmark$ denise.jodelet@wanadoo.fr
}

\begin{abstract}
The recent emergence of social and political movements calling for "common sense" and the use of the notion of "common" in philosophy and social sciences has led to the opening of a reflection on the social and scientific representations concerning them. After having mentioned some political uses of the notions of "common sense" and "common", we examine a notion that is closely associated with them: that of "community" on which S. Moscovici expresses a reserved position but introduces a new perspective on cybercommunities and the importance attached to affectivity in community groups. The ways of dealing with "common sense", identified over time, from antiquity to the present day, highlight certain recurrences from a double perspective. From a typological point of view, several characterizations are distinguished: through simple sharing, through the sameness of moral values and emotional dimensions, through rooting in daily experience, through its devaluation as a form of knowledge in relation to science, through rationality, through its potential for revolt or on the contrary through conformity. From a conceptual point of view, common sense is analyzed as an epistemic characteristic of a group, in its content, formation, transmission, and role in social cohesion. The latest developments in the reflection highlight its link with democracy and populism. The term "common" of recent appearance is situated opposite the notion of common goods which, after having focused on material realities, now integrates the facts and practices of knowledge, being the subject of a specific domain: the commons of knowledge. The common appears as a new way of approaching social relationships and responds to the desire to introduce a relational, ethical and political dimension into the analysis of social and change processes. In this respect, the call to the common presents affinities with the approach of social representations. The examination of the different scientific and secular representations regarding the notions of community, common sense and common makes it possible to establish connections with the perspective of the study of social representations and to open the way for new investigations.
\end{abstract}

Key words: social representations, common, common sense, community

Acknowledgements and Funding. I would like to thank Nikos Kalampalikis for his help in the literature search, as well as Hélène Ilbert and Saadi Lahlou for their contribution to the translation of this article.

(C) Jodelet D., 2021

(c) (7) This work is licensed under a Creative Commons Attribution 4.0 International License https://creativecommons.org/licenses/by/4.0/ 
"Terms circulate, but their meanings vary".

Gramsci

"Human history is the long succession of synonyms for the same word; contradicting it is a duty".

René Char

\section{Introduction}

The notion of "common" and those associated with it, "common sense" and "community", are currently receiving, in various currents of philosophical, scientific and political thought, meanings that could feed into epistemological reflection. To the point that the shifts in meaning linked to their use offer themselves as an interesting space to undertake a study of social representation that covers both the field of scientific knowledge and that of current knowledge.

After having made a conceptual and historical review of the treatment of the terms "community" and "common sense", this article will aim to identify the social representations that underlie discourses on the "common", particularly in the field of politics. On this occasion, reference will be made mainly to the French situation. Indeed, given the importance of the place that should be given to the context for a detailed analysis of social representation, it seemed preferable to refer to a national space familiar to the author, one where it is easy to find material relevant to the research. This option is all the more justified since the material used includes references to international literature, particularly in English, and reflect the current state of thinking. Nevertheless, given the challenges involved in using these terms, and particularly the term "common", there is no doubt that similar research can be undertaken in other national or political contexts.

\section{Why study "common"?}

A political phenomenon lies at the starting point of this question: the emergence of movements claiming to be "common" or taking a form of common practice, e.g. gathering in public places.

First there was the emergence of a new right-wing political movement called "common sense" ("sens commun"), formally claiming to be in the line of "Gramsci, theorist of cultural warfare". This political association, affiliated to the right-wing UMP party that became "Les Républicains", was created in 2013 following the "Manif pour tous" ("March for all"), which mobilized several hundred thousand people against abortion, homosexual unions, homoparentality, medically assisted procreation, gestational surrogacy, gender theory and schoolbased learning of traditional languages with communautarist risk. Transformed into a party in 2015, "common sense" aims to bring back to the forefront the notion of the common good, by reconciling politics with reality, to overcome the cleavage between the elites and the people who have simple values as one of its leaders says.

Another movement, "Les Veilleurs", also stemming from the "Manif pour tous", brought right-wing Catholics together, from 2013, around the "common in- 
tuition that unjust orders are in place", adopting a non-violent posture, with literary text readings and songs, in public places.

More recently, a conservative and sovereignist current of thought has been organized into a political force, calling on Orwell, his "new language", his "newspeak", and his analysis of the "thought police - thinkpol" as well as his concept of "ordinary decency", another name for common sense (Bégout, 2008). The call to common sense rises up against the power of the "Big Brother", assimilated to the "media pack, showbiztics, art, human rights, fearsome phalanx from within our own nation, and yet entirely committed to the voluntary service of the Other" (Raspail, 2011).

On the left, the "Nuit debout" (Standing up night) movement, launched in 2016 , in the wake of the "Indignados" movement in Spain, claims to be part of the Paris Commune. It differs from previous left-wing movements in the call for civil disobedience and non-violence. The first post-Marxist rally, held in 140 French cities, it would then be echoed in other European and Asian countries that are protesting against the dictatorship of the markets and its consequences, against the political class, and defending the right to freedom, equality and a dignified life.

It is striking that, in these movements, the reference to "common sense" or "common" is used to serve both right-wing and left-wing ideologies. This raises questions about the semantic roots of these notions and their historical uses in philosophy and social sciences. The notion of "common sense" has a long history that goes back to Greek philosophy and has continued to attract the attention of researchers interested in social thought. On the other hand, the notion of "common" (in singular) is very recent in France, at least in the use made of it in scientific and social fields. Both refer incidentally to the term "community" which has been the subject of numerous publications since the second half of the 20th century and corresponds to a clearly identified term or even field of research in the social sciences and in particular in psychology, with community psychology (Jodelet, 2011).

However, there is something striking about the emergence of today's sustained interest in these notions: its extreme recency. We see the emergence of the "common" theme from 2000, but it is remarkable that 9 out of 10 of the sixty or so references to articles or books were published only between 2010 and 2017. Similarly, the number of publications on the notion of "common sense" has increased considerably over the past 30 years. A review of the references used in a historical inventory of publications, from the 18th century to 2007 (Rosenfeld, 2014) shows that $60 \%$ of the theoretical texts identified were published after $1990^{1}$.

This appears to be an important area to explore, especially considering Moscovici's injunction to focus on emerging phenomena. Especially since this recommendation was implemented by Moscovici himself in a text in line with this specific issue and where he comments on the notion of "community" in relation to the use of digital networks, which will see that they constitute, with the domain of environment, the privileged places for a reflection on the "common".

${ }^{1}$ This count only concerns the introduction of the cited book containing 37 references, incurporating the first texts published from the 18th century up to 2007. 


\section{Moscovici's position on communities}

In a dialogue with the Italian sociologist Casalegno published in Italian in $2001^{2}$, Moscovici is led to discuss the notion of "community". He does not speak of "common", a term which, to my knowledge, is not in his usual vocabulary, at least not as a noun. This transformation of the adjective form retained by Moscovici, into the substantive form observed today with regard to the grouping of actors, is an illustration of the objectification process, specific to social representations, and of the pragmatic incarnation of an idea or phenomenon resulting from social interaction.

On the other hand, in the face of that phenomenon of "community", Moscovici adopts a position marked by two important features: scepticism towards the epistemic reality of communities; and the specification of the basis of what is termed "virtual community". "Theoretically," he says, "we don't know what a 'community' "' is. However, he makes an exception for traditional societies and "religious or cultural groups", characterized by strong stability, forms of living together, of co-acting, which are based on emotional ties and on the unity of place and time. In such cases, cohesion is ensured both by rituals, emotional ties that do not always imply harmony and by direct word-of-mouth communication, which has an institutive function. Otherwise, the idea of community would be a "fantasy" or "myth" and "one should rather speak of unstable forms of aggregation or association".

This last remark applies especially to exchanges within digital networks, "cyberspace", where participants are unaware of each other, having only one link between them: that of the representations they exchange. Moscovici uses William Gibson's description of cyberspace as a "consensual hallucination" where "information, images, sounds, texts and masks circulate", forming a new culture: cyberculture. It conveys representations that can be instantly communicated and shared, resulting in a "virtual community".

While a "real" community implies a contract, an institution, or a specific function, participation in the virtual community is expressed in a new way. Moscovici concludes that: "The cyber is in itself the root of a new social representation that spreads in the flow of life, and perhaps, a new way of representing, or another kind of representation that can reach the depths of the common reality". Through this representation, "shared language and feelings" are built. As a result, the virtual community is demanding a new concept because "we are dealing with a very recent phenomenon for which we do not know how it will evolve". A "phenomenon in an embryonic state". It would be a type of "representational sociability" based on something fundamentally new characterized by links that are totally different from those of other sociabilities. We are confronted with a "collective solipsism" insofar as there is no real interaction. In addition, the Internet can be seen as a kind of "mystical drug", creating something that is similar to a second state, a "community in a trance". The "magical" aspect of this novelty lies in the fact that the use of technology is dissociated from knowledge.

\footnotetext{
${ }^{2}$ Text translated into French in 2005 and Portuguese in 2006.
} 
The presentation of this text by Moscovici, retaining only what is in consonance with the problematics of this chapter, allows us to point out an original contribution of his thought and his way of proceeding to approach novelty. The innovations I will discuss here concern the notions of "common sense" and "common". Regarding that of "community", uses of the term that could be considered new, referring to religious communitarianism, do not fall within the scope of our inquiry. However, the fact that it has been widely studied in the social sciences deserves to be examined, especially to see if the emotional dimension that Moscovici detects in it is represented.

\section{The notion of community in the social sciences}

Indeed, in social science approaches to the notion of "community", attention is focused on the norms that govern situations, social actions and social relationships. The latter are defined either in terms of power relations between dominant and politically or professionally dominated, or in terms of exclusion-inclusion relations between the same and the different. But the way of conceptualizing community, characterized by the sharing of a material or symbolic commodity, of the same origin, fate or activity, is very diverse and has evolved over time. Two main trends can be identified, one empirical and the other theoretical.

In some cases, communities are referred to as concrete social groups to which observation and intervention relate. These areas are then defined either by their territorial extension, or by the sharing of the same life-form, the same activity or the same culture, or by local and neighbouring relations that contribute to mold, through exchanges, a collective spirit. They may also be institutional organizations such as the family, school, hospital. The reference to the cultural and social norms that organize transactions within the community in question is therefore essential. An example can be found in the ecological model of Behavior setting, proposed by Barker (1968).

Other authors use the notion as a theoretical construct to provide a framework for objectifying social relations. The community is then treated as a symbolic and material space, with a memory loading, where social identity is molded and a sense of belonging and positive or conflictual interactions with members of its group and those of other groups are developed. This construct would promote an analysis of the link between the individual and society and would constitute an optimal approach to psychosocial phenomena, in particular those related to the development of knowledge through dialogical exchange in the public space (Jovchelovitch, 2006).

On the other hand, the theoretical construct refers to the utopian character or ideological operator status of the notion of community. Nisbet (1966/1984) showed that there is a correspondence between the advances of individualism and the revival of community utopias, and vice versa. The community then becomes a space of reference referring to past forms of socialization that can be negative or ideal. Thus, in the Enlightenment era, when the idea of a contract between free men and the struggle against injustice and exploitation was advocated, the idea of community was rejected because of its association with feudalism and medieval civilization. In the 19th century, forms of life based on tradition were opposed in the name 
of economic rationality and administrative reform. At the same time, proponents of social conservatism defended the communitarian model threatened by individualism and rationalism. In recent modernity, community has become the subject of debate between those who support social progress and those who oppose modernization. In the second modernity, community life forms are nowadays sought in response to negative assessments of pessimistic observations about the evolution of the contemporary world. This perspective has been criticized as a comfortable but illusory refuge attitude in the face of the upheavals caused by globalization (Bauman, 2001).

Beyond this multiplicity of perspectives, it can be seen that, since Tonnies (1887/1977), the idea of "community" (Gemeinschaft), as organic solidarity, has been opposed to that of "society" (Gesellschaft), as mechanical solidarity. This opposition has been taken up and commented on by many thinkers from European and Anglo-Saxon countries. Moscovici himself draws inspiration from it in the commentary discussed above. More recently, the phenomenon of "community" or "communitarian" has been seen as a sign of a retreat into ethnic, cultural or religious particularities that isolates from the citizen community and universal values, republican or otherwise. This particularist indexation, particularly opposed in France, had already been stigmatized by sociologist Simmel (1908/2013) who saw in communities a danger preventing the individual from joining the values of universality.

Nevertheless, in the human sciences today, this term has a positive meaning associated with multiculturalism and the identity claims assumed by subjects enjoying freedom of choice. We can see (Wieviorka, 2008) the emergence of a new modernity where the opposition between the legacy of the Enlightenment and the attachment to traditions is diluted and where any national, cultural, linguistic or religious hegemony is challenged. This is where "community" and "common sense" and "common sense" connect.

To understand these connections, it is useful to examine how disciplines that use the notion of community specify it. In history, we will speak of a community for groups that have been formed over time, in a given place, and share the same culture and language. This global perspective is echoed in other human sciences (sociology or anthropology) when they refer to groups of people who live and act in the same space, such as the family, school, etc. or to groups sharing the same culture or history. Sociology adds extensions that are relevant to our purpose. On the one hand, the gathering behind shared values or interests, as is the case for communities that defend specific beliefs (religious or spiritual communities), identity or rights such as movements defending gender identities (e.g. LGBTI ${ }^{3}$ or feminist movements), or conditions (e.g. user groups in public institutions).

Finally, new conceptualizations regard scientific and technological research and innovation activities, from "scientific communities", analysed today in terms of networks of actors (Latour, 1989) to "knowledge communities" (Dupouët et al., 2006), informal groupings around a question, a shared objective, based on volun-

${ }^{3}$ Today, in addition to the acronym LGBT, I am added to designate Intersex people whose anatomical differences do not allow them to fall within the traditional definition of a man or a woman. This category would concern one person in 2000. 
tary action and aimed at creating and maintaining knowledge in organizations or within virtual networks. These communities, also known as "knowledge" or "cognitive" communities, make it possible to exchange and transform know-how, to make tacit knowledge explicit in order to operationalize it to respond to specific requests. These relations of exchange will gradually create a common "identity" and be consolidated by the creation of shared social norms. The recent developments of a sociological approach to communities (ecological, identity defence or knowledge) as networks of relationships, make it possible to grasp how exchanges that engage between actors sharing the same activity, the same interest, the same objective can produce creative and autonomous collectives designated as "common", and, consequently, develop new social representations.

To conclude this quick overview, it can be said that Moscovici's comments were pioneering, proposing to give importance to the affectivity neglected by the social sciences and engaging in the study of a new and specific type of community, the cyber communities. This calls for an incidental remark. In Moscovici's latest writings, we see the avenues for broadening the approach to social representations. With his texts on victimization, as underlines Jodelet (2015), he introduces a historical and ethical dimension into the analysis of social representations, advocating a "historical-ethical" approach. In his reflections on the community, he emphasizes the need to reintroduce an emotional dimension into his analysis. This is the marking of a field of exploration of social representations whose novelty is of great relevance for our time.

\section{Novelty of a thematization}

This novelty is confirmed by the examination of the concepts of common sense and common. As products of interaction, social representations have a "common" character of which it would be interesting to identify all the implications. Moreover, to the extent that the notions of "common sense" and "common" are thematized in a variable way according to periods or research trends, they prove to be an interesting object for a study of social representation.

The renewed interest in social reflection that these concepts are experiencing today has a direct impact on the scientific and political fields. Interestingly in these fields both concepts share a rare particularity: they receive antithetical meanings. There are positive and negative interpretations given, both in the scientific and social fields. Judgments made on common sense, based either on epistemological or moral reflection, exemplify this polarity.

Common sense knowledge and scientific knowledge are inseparable concepts whose boundaries often appear to be blurred. As a type of knowledge the validity of the former has been challenged by positivism with regard to scientific knowledge, while retaining its legitimacy as an object of scientific knowledge. Thus Durkheim, who denied any interest in common sense as a set of "pre-concepts", makes collective representations a central object for sociology. The whole tradition of comprehensive sociology, since Weber, values common sense as an object of study, as Schütz states: "the objects of thought constructed by the social scientist, in order to grasp social reality, must be based on objects of thought constructed by the common sense of men living daily in the social world. In this way, 
the constructions of the social sciences are, so to speak, constructions of the second degree, i.e. constructions of constructions made by actors on the social scene, whose behaviour the researcher must observe and explain according to the procedural rules of his science" (Schütz, 1998). Regarding the "common" we see opposing conceptions based on sharing and "living together" and the refutation of the existence of a "common world" in the name of pluralism of cultures and natures, relations with living worlds and spiritual worlds, the existence of pluriverses (Latour, 2011).

Could it be these two terms are controversial because they refer to realities relating to human modes of doing or being, spontaneous and shared, whether cognitive or practical? In any case, they favour the projection of representative constructs that may be interesting to examine in their genesis and contemporary use. Working together on the notions of "common" and "common sense" is a way of studying a representational system, whether in terms of its construction in the scientific world, among groups of researchers, or in terms of its political uses in public debates and within political parties.

\section{About common sense}

The notion of common sense has a long history (Guenancia, Sylvestre, 2006) that goes back to Aristotle. The latter considered it a sensitive capacity enabling to synthesize the various sensations that a subject receives from an object and, and classified it within practical wisdom, "phronesis". This conception crossed time, to be found in H. Arendt $(1991,1995)$ who considers it a "sixth sense that adjusts the other five to a common world". She socializes common sense, by posing that the reality of the perceived world is conditioned by the recognition that it appears in a similar way in others. Thus, the subject would exert his or her judgment as a member of a community, making common sense a general quality of the citizen (Gadamer, 1996).

In connection with this revival, common sense is today the object of sustained interest on the part of philosophers, sociologists and politicians who refer to some classical theorizations in philosophy, in particular: in Italy, Vico (1744); in France, Descartes (1637), Buffier (1704); in England, Paine (1776), or Reid (1785) who founded the Scottish School of Common Sense, Moore (1925); in Germany, Kant (1790). In the various theoretical texts, common sense receives contents, meanings, uses, and obeys principles that vary with times and cultures. It has been approached either from a typological point of view or from the point of view of its epistemic characteristics.

From a typological point of view, it can be:

- reduced to the simple fact of sharing;

- located at the origin of the social bond in that it is related to identical moral values, feelings, similar emotional dimensions;

- rooted in daily experience, and not ideological and thus valued in terms of expertise knowledge, and partisan spirit;

- referred, on the contrary, to current, vulgar knowledge, as opposed to scientific knowledge;

- underlined in its rationality, its universality, "the first degree of reason" as Reid wrote in the 18th century, and, as Boudon (2006) now defends it, as the em- 
bodiment of a spontaneous rationality against the relativist current in the social sciences;

- representing the promise of an ideal of humanity and civility;

- associated with the idea of revolt, with the projection of a rational plan for the future calling into question the established authorities, as theorized by Paine who, in the 18th century, adopted a revolutionary posture both in the political field and in the field of religious beliefs and institutions;

- inducing conformity, to the point of constituting according to Bourdieu (1980) a "spectacular instrument" of domination.

Conceptually, common sense is distinguished from common knowledge in that it refers to "social dispositions acquired to think, feel, move, and not to explicit mental states" (Paternotte, 2017). Several variants have been distinguished as an epistemic characteristic of a group:

- "propositional" in that it refers to the beliefs of a group;

- "procedural", in that we study how it is formed;

- "communicative", in that we consider the way it is transmitted;

- "communautary" in that it refers to one's role within a group.

The diversity of these approaches, as well as the recent orientations of the reflections on common sense, nowadays leads to the fact that "the very idea of common sense occupies a central place in political life and in particular in democracy" to which it "gives its popular face" (Rosenfeld, 2014). As the pillar of democracy, in that it is "the most political faculty of man" (Arendt, 1991), common sense also provides the foundation and justification for the defence of the status quo and traditional values by the conservative and sovereignist right. It will also serve as a referent for populism, which Lanclau (2008) has shown to be characterized by the absence of a foundation on doctrinal principles. These shifts in meaning are due to the fact that notions of common and common sense are embedded in different and conflicting ideological references. This observation is an invitation to deepen their study as a space for meeting different types of scientific, political and social representation.

\section{Commons and common goods}

The emergence of the term "common", and its use as a category of social and political analysis, came later and evolved. Initially, this term was used in the ecological movement and economic reflection of the 1980s. It was first used in the plural, the "commons", in conjunction with that of "common goods". It was then extended to digital media, new forms of induced communication, within social networks, via the Internet and virtual media. Recently it entered the political and ethical sphere, under the form of "common" in the singular.

The "common goods" refers to material, natural and cultural resources that are accessible to all, shared in common, not susceptible to private ownership. But unlike the latter, "commons" are not understood as pre-existing things to be managed by a community or a group of users. They refer to social relationships subject to rules of use, sharing or co-production that structure a common management (Dardot, Laval, 2010, 2014). To this extent, the "commons" are distinguished from the "common", as a "social product" as currently developed by philosophy and the social sciences. 
Although the first uses of the term "commons" date back to Roman antiquity and the English Middle Ages, the problems concerning it are of recent appearance in the social sciences. They spread from 1968 onwards, following an article by Harding entitled "The tragedy of commons", which warned of the harmful consequences of a collective use of natural common goods, leading to an in-depth reflection on the governance of common goods (Ostrom, 2010). Moreover, these issues have been extended to the cultural sphere with the inclusion of the various arts, audiovisual and digital information and since 2007 to the "knowledge commons" to which I have already alluded. It is in this respect that I will focus on this subject before addressing the notion of common, as it is used in the social sciences and social philosophy in France.

The "commons of knowledge" (Hess, Ostrom, 2007) refer first and foremost to the digital forms of storage, sharing and collective access to knowledge and the social practice they generate. Moscovici referred to them in the text quoted above. But this text, dating from 2001 and centred on the form of communication implied by digital resources, could not take into account the contributions of the stream of study on knowledge commons, covering their supports (the different types of human collectives), their forms (scientific or profane) and their functions (scientific, cognitive or political). The field of study for which he called development now has contributions that enrich the problem.

While other common goods imply scarcity and are classified into four categories according to whether their use is exclusive or not, implies or not rivalry, the commons of knowledge are abundant, accessible to all, do not imply competition or constraining management, and can give rise to collective actions. This has led to alternative models of knowledge production in both the scientific and social spheres. This area is too vast to be explored here and would deserve special treatment, which may be of interest in the future.

Through this process, the treatment of the notion of common has become autonomous, integrating new connotations, broadening its use, with regard to objects (libraries, for example), practices of open collaboration (the "crowdsourcing" specific to cyberspace, for example), or social organizations related to knowledge and representations (communities of scholars or social movements, for example). This investment of the common by political and scientific discourses will be matched by a revival of references to the "popular", conceived in original terms where economism and law are replaced by ethics and communication.

\section{Of political and ethical uses of "common"}

One of the particularities of the current use of the notion of common lies in its political and ethical dimensions. On the one hand, it is differentiated from the notion of the common good in that it is neither a good nor an object, but a "mobilization", a political practice of actors who want to organize common social life (Douce, 2017). On the other hand, it is identified with the ordinary, the everyday, as it is experienced, thought of in the social environment. Emerson already said in 1837: "I embrace the common, I explore the familiar, I am at their feet". Since 2010, the word "ordinary" has appeared more and more in the writings of political scientists (Larivière, Weisbein, 2017). With the identification of 
the common in these terms, the "popular" returns as distinct from, and in opposition to, order emanating from state and entrepreneurial power, political parties or dominant groups. It will inspire contemporary social movements such as Occupy in the United States, Los indignados in Spain, Nuit Debout and Les gilets jaunesoin France, the Arab Spring, the occupation of Taksim Square in Turkey, claiming to be part of a common mobilization against political and capitalist oppression. The common goes so far as to encourage citizen practices, mobilizing skills to achieve what is good and fair for the community, in a new form of governance. Thus, some municipalities, such as Barcelona in Spain and Bologna in Italy, are seeking to lay the foundations for a collaborative city. This movement tends to expand with the creation in 2016 of a "European Assembly of Commons".

Finally, the idea of a common approach involves a new vision of the social (Collomb, 2011). Individuals are no longer thought of as isolated entities that connect. We no longer talk about interaction but of "intra-action", according to the neologism coined by Barad (2007). While interaction presupposes separate entities before they interact, the concept of intra-action refers to the idea that individualities emerge through relationships and from being in relation. There is no longer a static social state, social relations governed by objective necessity, but relations in the making. This leads to the proposal of a new psychosociological perspective "methodological relationalism" making social relations the primary entities characterizing individuals and institutions (Corcuff, 2011).

Everything happens as if, in an ideological space where reflection in terms of class and class struggle, inspired by Marxism, has lost its hold, and where the alterglobalization movement is losing momentum, the common offered a new way of talking about social relations and establishing an approach that escaped liberalism and its avatars - commodification (linked to mercantilism), the power of multinationals (corporatization) and the expansion of private property (propertization) - by introducing rules of use, sharing and co-production (Sauvêtre, 2014). The call to the common would open a "new age", with the transition from critical analysis to the construction of alternative proposals.

It should be noted, however, that for some thinkers (Négri, Hardt, 2009), reflection on the common reconnects with a Marxist tradition. With the return of economic questions (work, poverty, crisis, etc.) would end a "sort of post-marxist cycle" (Haber, 2010), centred on gender and race relations, involving recognition. But it should be stressed that this reintroduction of the importance of work gives way to intersubjectivity. This is based on communication. This new orientation is particularly represented in the professions of care, maintenance and education, which are considered as an "expansion of the common" and are classified as immaterial work, or as "production of the common" (Laugier, 2011).

An illustrative example of this process is the "care" which is "the basis of the concrete manufacture of the common", conceived as a "city of words". This implies a "democratic conversation" giving voice to those in subordinate or marginalized positions, demanding attention to others, a sensitivity to vulnerability and responsibility. All these proposals lead to a new conception of relationships and the social as an organization that unleashes the power of the common, through communication. Thus, the common, arising with environmental concerns, 
in the void left by the great stories heralding progress, in the bitterness caused by the failures of liberal democracy, offers itself as a recourse for political consciousness. While it can serve as a mask to cover, in the spirit of the times, the populist currents of the right and left, it is recognized by the social sciences as a new form of sociality that brings hope.

\section{Conclusion}

Regarding the schools of thought of which a picture has just been sketched, certainly a very limited and non-exhaustive one, but targeting the pivotal points in the development of the idea of common, we can only be struck by the coincidence with the lines drawn by Moscovici for the development of our field of research. The rehabilitation of everyday thought, the role of exchange and social communication, intersubjectivity, reliance of the subject on the Other, etc., meet central themes in the approach to social representations. Of course, it is regrettable that no reference is made to the contribution of our field of study, as I had the opportunity to do with the latest sociological contributions on social thought (Jodelet, 2018).

But we can only be pleased to note the centrality of our perspective in the most recent developments in scientific thought on social issues. It remains for us to contribute to this debate by adjusting the themes of our research to the hottest questions of our contemporaneity. More specifically, one could focus on the place and role of social representations seen both as a product and as an process of the common. In examining the social representations of collective social practices or produced by them, one could examine in greater depth the criteria according to which groups are conceived or conceived themselves as common or communities, the substrate provided by belief systems and ideological options for the construction of a common vision of social and political reality, the models of thought and the representations of socio-political practice that result from them.

\section{A final remark concerning the community of study of social representa-}

tions. One of the possible side effects of looking at the common issue is to think about our scientific community. At Moscovici's request, the Serge Moscovici World Network (Réseau Mondial Serge Moscovici: REMOSCO) was created to replace the European Laboratory of Social Psychology at the Fondation Maison des Sciences de l'Homme. Would it not be useful to use this institutional framework to share our knowledge scattered across different countries? In other words, through our collective collaboration, we can build one of these "knowledge commons" that would allow us to share our knowledge and encourage exchanges between researchers who often work, in different contexts, on similar problems and would benefit from the mutual contributions of their colleagues? This spin-off of our community collaboration could produce innovative scientific effects, as the symposium from which this book is derived illustrates.

\section{References}

Arendt, H. (1991). Juger. Sur la philosophie politique de Kant. Paris: Seuil. Arendt, H. (1995). La Crise de la culture, Folio-essais.

Barad, K. (2007). Meeting the Universe Halfway. Durham \& London: Duke University Press. 
Barker, R.G. (1968). Ecological psychology: Concepts and methods for studing the environmental of human behavior. Stanford: Stanford University press.

Bauman, Z. (2001). Community: Seeking safety in an insecure world. Cambridge: Polity Press.

Bégout, B. (2008). Décence ordinaire. Paris: Allia.

Boudon, R. (2006). Renouveler la démocratie. Eloge du sens commun. Paris: Odile Jacob.

Bourdieu, P. (1980). Le sens pratique. Paris: Ed Minuit.

Bouvet, L. (2015). Pour un républicanisme du commun. Le débat, 186(4), 159-165. https://doi.org/10.3917/deba.186.0159

Buffier, C. (1704). Examens des préjugés vulgaires, pour disposer l'esprit à juger sainement de tout. Paris.

Collomb, C. (2011). Ontologie relationnelle et pensée du commun. Multitudes, 45(2), 59-63. https://doi.org/10.3917/mult.045.0059

Corcuff, P. (2011). Les nouvelles sociologies. Paris: Armand Colin.

Dardot, P., \& Laval, C. (2010). Du public au commun. Revue du MAUSS, 35(1), 111-122. https://doi.org/10.3917/rdm.035.0111

Dardot, P., \& Laval, C. (2014). Commun. Essai sur la révolution au XXIème siècle. Paris: La Découverte.

Douce, J.E. (2017). Société et communauté: le tracé des frontières et l'idée du commun. Communication et organisation, 52, 47-58. Bordeaux: Presses Universitaires de Bordeaux.

Dupouët, O., Cohendet, P., \& Creplet, F. (2006). La gestion des connaissances: Firmes et communautés de savoir. Paris: Editions Economica

Emerson, R.W. (1837). The American Scholar. (Trad. "Le savant américain". Critique, 1992, pp. 541-542).

Gadamer, H.-G. (1996). Vérité et méthode. Paris: Seuil.

Guenancia, P., \& Sylvestre, J.P. (2006). Le sens commun. Dijon: Editions Universitaires de Dijon.

Haber, S. (2010). La puissance du commun. La Vie des Idées. Retrieved February 2, 2021, from https://laviedesidees.fr/La-puissance-du-commun.html

Harding, G. (1968). The tragedy of the commons. Science, 162, 1243-1248.

Hess, C., \& Ostrom, E. (Eds.). (2007). Understanding knowledge as commons. Cambridge: MIT Press.

Jodelet, D. (2011). L'approche de la dimension sociale dans la psychologie communautaire. In T. Saïas (Ed.), Introduction à la psychologie communautaire (pp. 27-36). Paris: Dunod.

Jodelet, D. (2015). La victimisation vue sous l'angle de la psychologie sociale: L'apport de Serge Moscovici. Sociétés, 130(4), 41-52.

Jodelet, D. (2018). Sciences sociales et représentations: Etude des phénomènes représentatifs et processus sociaux, du local au global. Sociedad e Estado, 33(2), 423-442. https://doi.org/10.1590/s0102-699220183302007

Jovchelovitch, S. (2006). Knowledge in context. Representations, community and culture. New York: Routledge.

Kant, E. (1790). Critique de la faculté de juger. Paris: Vrin (French edition 1993).

Larivière, C.J. de, \& Weisben, J. (2017). Dire et faire le commun. Les formes de la politisation ordinaire du Moyen Age à nos jours. Politix, 119(3), 7-30. https://doi.org/10.3917/pox.119.0007

Latour, B. (1989). La science en action. Paris: La Découverte.

Latour, B. (2011). Il n'y a pas de mode commun: Il faut le composer. Multitudes, 45(2), 38-41. https://doi.org/10.3917/mult.045.0038

Laugier, S. (2011). Le commun comme ordinaire et comme conversation. Multitudes, 45(2), 104-112. https://doi.org/10.3917/mult.045.0104

Michea, J.C. (2003). Orwell éducateur. Paris: Climats.

Moore, B.G.E. (1925). A defense of common sense. In E. Muirhead (Ed.), Contemporary Britsh Philosophy. Londres: Allen \& Unwin Ltd. 
Moscovici, S. (2005). Mémoire, rituels et cyber-représentations In F. Casalegno (Ed.), Mémoire quotidienne. Communautés et communication à l'ère des réseaux. Laval: Presses Universitaires de Laval. (Traduction en Portugais. 2006. Memorira cotidiana. Comunidades et comunicaçao na era das redes. Porto Alegre: Sulina).

Négri, A., \& Hardt, M. (2009). Commonwealth. Harvard: Harvard University Press.

Nisbet, R.A. (1966). The sociological tradition. New York, Basic Books. (Traduction Française. 1984. La tradition sociologique. Paris, PUF).

Ostrom, E. (2010). Gouvernance des biens communs: Pour une nouvelle approche des ressources naturelles. Paris: De Boeck.

Paine, T. (1776). Le sens commun. (Traduction Française. 1992. Paris: Aubier).

Paternotte, C. (2017). Sens commun et connaissance commune. Les études philosophiques, 174(4), 555-578. https://doi.org/10.3917/leph.174.0555

Raspail, J. (2011). Le camp des saints. Paris: Robert Lafont.

Reid, T. (1785). Essai sur les facultés intellectuelles de l'homme. (Traduction Française. 2007. Paris: L'Harmattan).

Rosenfeld, S. (2014). Le sens commun. Rennes: Presses Universitaires de Rennes.

Roviello, A.-M. (1987). Sens commun et modernité. Paris: Vrin.

Sauvêtre, P. (2014). Le commun contre l'Etat néolibéral. La Vie des Idées. Retrieved February 2, 2021, from https://laviedesidees.fr/Le-commun-contre-l-Etat-neoliberal.html

Schütz, A. (1998). Éléments de sociologie phénoménologique. Paris: Editions L'Harmattan.

Simmel, G. (1908/2013). Sociologie. Études sur les formes de la socialisation. Paris: Presses Universitaires de France, "Quadrige".

Tonnies, F. (1887/1977). Communauté et société. Catégories fondamentales de la sociologie pure. Paris: Presses Universitaires de France.

Vico, G. (1744.) La science nouvelle. Paris: Fayard.

Wieviorka, M. (2008). Neuf leçons de sociologie. Paris: Robert Laffont.

Article history:

Received: 25 February 2021

Revised: 23 April 2021

Accepted: 10 May 2021

\section{For citation:}

Jodelet, D. (2021). The Notion of Common and Social Representations. RUDN Journal of Psychology and Pedagogics, 18(2), 299-314. http://dx.doi.org/10.22363/2313-1683-2021-182-299-314

\section{Bio note:}

Denise Jodelet, Ph.D., is a Research Director (Emeritus) at the School for Advanced Studies in the Social Sciences (Paris, France). She is a social psychologist, specialized in the study of Social Representations and has directed various research programs and doctoral thesis (particularly in the domains of environment, health, memory, religion and arts) at the Laboratory of Social Psychology of the School for Advanced Studies in the Social Sciences. She has taken the direction of this laboratory after its founder, Serge Moscovici. Her work has led her to establish stretch collaborative relations with diverse universities in Europe, Latin and South America, Asia and Africa. She has published many books and articles, of theoretical and empirical nature, on social representations, pointing particularly on the fields of madness and mental health, body, health, memory, environment. She is currently oriented towards meaning construction and transmission through art and religion, giving attention to the imaginary dimension of social representations. E-mail: denise.jodelet@wanadoo.fr 


\title{
Понятие «общее» и социальные представления
}

\author{
Д. Жоделе \\ Высшая школа социальных наук, \\ Франиузская Республика, 75006, Париж, Boulevard Raspail, д. 54 \\ $\checkmark$ denise.jodelet@wanadoo.fr
}

\begin{abstract}
Аннотация. Недавнее появление социальных и политических движений, которые призывают к «здравому смыслу» (common sense), и использование понятия «общее» (common) в философии и социальных науках инициировали интерес автора к размышлениям о социальных и научных представлениях, касающихся этих понятий. Вслед за обсуждением ряда политических коннотаций понятий «здравый смысл» и «общее» будет рассмотрено понятие, которое тесно связано с ними, - «сообщество» (community). В отношении этого понятия С. Московиси выражает сдержанную позицию, однако предлагает новый взгляд на киберсообщества и важность, придаваемую аффективности в группах сообщества. Рассматриваются два основных способа трактовки понятия «здравый смысл» в исторической перспективе от античности до наших дней. С типологической точки зрения принято различать ряд очень разных характеристик, присущих и объясняющих «здравый смысл»: через сведение его к факту простого разделения мнений в обществе; через исходную социальную близость, связанную с идентичностью моральных ценностей и эмоциональных измерений; через укорененность в повседневном опыте; через его девальвацию как формы знания по отношению к науке; через подчеркивание его рациональности; через акцентирование его потенциала для восстания и революционных взглядов или, наоборот, через трактовку его как индуцирующего конформность в обществе. С концептуальной точки зрения «здравый смысл» анализируется как эпистемологическая характеристика группы в ее содержании, формировании, передаче опыта и роли в социальной сплоченности. Современные воззрения подчеркивают его связь с демократией и популизмом. Понятие «общее», появившееся в последнее время, все чаще встречается в сочетании с понятием «общие блага» (common goods), изначально фокусировавшимся на материальных реалиях, теперь же - объединяющим факты и практики знания, являясь предметом определенной области - общего знания. Таким образом, «общее» появляется как новый способ подхода к социальным отношениям, что соответствует стремлению ввести отношенческое, этическое и политическое измерения в анализ социальных процессов и процессов изменения. В этом отношении призыв к исследованию «общего» имеет сходство с подходом социальных представлений. Изучение различных научных и обыденных представлений о понятиях общности, здравого смысла и общего позволяет установить связи с перспективами изучения социальных представлений и обозначить пути для новых исследований.
\end{abstract}

Ключевые слова: социальные представления, общее, здравый смысл, общность

Благодарности и финансирование. Автор благодарит Никоса Калампаликиса за помощь в подборе литературы, а также Элен Ильбер и Саади Лалу за вклад в перевод статьи с французского на английский язык.

\section{История статьи:}

Поступила в редакцию: 25 февраля 2021 г.

Принята к печати: 10 мая 2021 г. 


\section{Для цитирования:}

Jodelet $D$. The notion of common and social representations // Вестник Российского университета дружбы народов. Серия: Психология и педагогика. 2021. Т. 18. № 2. C. 299-314. http://dx.doi.org/10.22363/2313-1683-2021-18-2-299-314

\section{Сведения об авторе:}

Жоделе Денис, Ph.D., почетный руководитель исследований Высшей школы социальных наук (Париж, Франция). Как социальный психолог, специализирующийся на изучении социальных представлений, она руководила многими исследовательскими проектами и докторскими диссертациями (прежде всего, связанными с проблематикой социальных представлений относительно окружающей среды, здоровья, памяти, религии и искусства), выполняемыми в лаборатории социальной психологии Высшей школы социальных наук. Сменила на посту ее основателя Сержа Московиси. За долгие годы работы она установила тесное научное сотрудничество с коллегами из различных университетов Европы, Латинской и Южной Америк, Азии и Африки. Денис Жоделе опубликовала много книг и научных статей теоретического и эмпирического характера, посвященных исследованиям социальных представлений относительно психического здоровья и безумия, телесности и физического здоровья, памяти, окружающей среды и др. В настоящее время она занимается проблемами конструирования смысла, уделяя особое внимание иконической составляющей социальных представлений. E-mail: denise.jodelet@wanadoo.fr 